\title{
Maciej Frendzel
}

Uniwersytet Łódzki

e-mail: mfrendzel@uni.lodz.pl

\section{PREZENTACJA KAPITALU PODSTAWOWEGO W SPRAWOZDANIACH FINANSOWYCH SPÓLEK NOTOWANYCH NA GPW W WARSZAWIE - WYBRANE PROBLEMY}

\section{PRESENTATION OF SHARE CAPITAL IN FINANCIAL STATEMENTS OF COMPANIES LISTED ON THE WARSAW STOCK EXCHANGE - SELECTED ISSUES}

DOI: $10.15611 /$ pn.2017.484.06

JEL Classification: M41

\begin{abstract}
Streszczenie: W artykule podjęto problematykę prezentacji kapitału podstawowego w sprawozdaniu finansowym przygotowanym na podstawie Międzynarodowych Standardów Sprawozdawczości Finansowej (MSSF). Obowiązek wyróżniania kapitału własnego w bilansie wynika zarówno z regulacji krajowych (ustawy o rachunkowości), jak i MSSF. Celem artykułu jest analiza wytycznych dotyczących prezentacji kapitału podstawowego, jego nazewnictwa stosowanego przez niefinansowe podmioty notowane na GPW w Warszawie, analiza jego istotności w stosunku do innych pozycji bilansowych, a także ustalenie, czy prezentowany kapitał reprezentuje kwoty wykazane jako kapitał zarejestrowany w Krajowym Rejestrze Sądowym. Badania wskazują, że przyjęte przez jednostki gospodarcze sposoby prezentacji kapitału podstawowego mogą wprowadzać w błąd osoby analizujące sprawozdania finansowe. Na potrzeby artykułu dokonano krytycznej analizy literatury i regulacji rachunkowości oraz przeanalizowano dane podawane przez podmioty notowane na GPW.
\end{abstract}

Słowa kluczowe: kapitał podstawowy (zakładowy), kapitał własny, prezentacja kapitału podstawowego.

Summary: The article discusses the presentation of share capital in the financial statements prepared under the International Financial Reporting Standards (IFRS). The obligation to distinguish share capital in the balance sheet results both from national regulations (the Accounting Act) and from IFRS. The objective of this article is to analyze guidelines for the presentation of share capital, its nomenclature used by non-financial entities listed on the Warsaw Stock Exchange, its significance in relation to other balance sheet items, and to determine whether the presented capital represents amounts registered as registered in the National Court Register. The studies conducted show that the methods of presentation of share capital adopted by business entities may mislead the person analyzing the financial statements. For 
the purposes of this article, critical analysis of literature and accounting regulations was taken and the data provided by entities listed on the Warsaw Stock Exchange were analyzed.

Keywords: share capital, equity, presentation of share capital.

\section{Wstęp}

W polskim porządku prawnym kapitał zakładowy (zwany również kapitałem podstawowym) jest konieczny dla utworzenia spółek kapitałowych w postaci spółki z ograniczoną odpowiedzialnością i spółki akcyjnej ${ }^{1}$. Odzwierciedla on wartość nominalną wyemitowanych akcji lub udziałów ${ }^{2}$ i jest traktowany jako element kapitału stałego finansującego działalność gospodarczą przed długi okres.

W kolejnych latach funkcjonowania spółki relacja kapitału podstawowego do kapitału własnego (wartości księgowej spółki) oraz wykazywanych przez nią aktywów ulega zmianom, co wiąże się m.in. z wykazywanym w kapitale własnym wynikiem finansowym danego okresu i lat ubiegłych, przeszacowaniami ujmowanymi w kapitale, a także powstaniem ewentualnych kwot z nowych emisji w postaci agio emisyjnego, wykazywanego w ramach kapitału zapasowego [Ustawa z 15 września 2000, art. 154 par. 3 i art. 396 par. 2].

Problematyka ujmowania, wyceny i prezentacji kapitałów własnych, a w szczególności kapitału podstawowego nie budzi szerokiego zainteresowania wśród naukowców podejmujących zagadnienia sprawozdawczości finansowej i rachunkowości finansowej. Liczni autorzy, którzy odnoszą się do problemu kapitału podstawowego (zwłaszcza w kontekście prezentacji bilansu) [np. Walińska 2014, s. 346; Gos 2012, s. 19], koncentrują się zazwyczaj na opisie zasad jego początkowego ujęcia. W tym kontekście wyróżnianie kapitału podstawowego w sprawozdaniu finansowym (w bilansie lub w sprawozdaniu z sytuacji finansowej) wydaje się oczywistą praktyką, zwłaszcza że jego prezentacja w bilansie jest wymagana przez regulacje rachunkowości (ustawę o rachunkowości).

W tym kontekście nasuwają się następujące pytania badawcze:

1. jakie zasady identyfikacji kapitału podstawowego zawierają regulacje międzynarodowe rachunkowości,

2. jakie nazewnictwo stosują niefinansowe podmioty notowane na GPW w Warszawie w odniesieniu do kapitału podstawowego,

\footnotetext{
${ }^{1}$ Wymagania te wynikają odpowiednio z art. 154 par. 1 i art. 308 par. 1 Kodeksu spółek handlowych [Ustawa z 15 września 2000]. Należy podkreślić, że w niektórych porządkach prawnych do utworzenia analogicznych spółek nie jest konieczne wnoszenie kapitału zakładowego.

${ }^{2}$ Przypisanie wartości nominalnej do każdej akcji/udziału jest charakterystyczne dla krajów z kręgu prawa kontynentalnego. W niektórych jurysdykcjach prawnych (np. Kanada) akcje/udziały nie mają (nie muszą mieć) przypisanej wartości nominalnej.
} 
3. jaka jest materialność kapitału podstawowego w niefinansowych spółkach notowanych na GPW w Warszawie do kapitału własnego ogółem oraz do łącznej wartości prezentowanych aktywów,

4. czy kapitał prezentowany przez niefinansowe podmioty notowane na GPW w Warszawie jako podstawowy reprezentuje kwoty wykazane jako kapitał zakładowy zarejestrowany w Krajowym Rejestrze Sądowym.

$\mathrm{W}$ niniejszym artykule podjęto próbę odpowiedzi na powyższe pytania. W tym kontekście celem pracy jest analiza wytycznych dotyczących prezentacji kapitału podstawowego, nazewnictwa stosowanego przez niefinansowe podmioty notowane na GPW w Warszawie w odniesieniu do kapitału podstawowego, analiza istotności prezentowanego kapitału podstawowego do kapitału własnego ogółem oraz do łącznej wartości prezentowanych aktywów, a także ustalenie, czy prezentowany kapitał reprezentuje kwoty wykazane jako kapitał zarejestrowanych w Krajowym Rejestrze Sądowym.

Na potrzeby artykułu dokonano krytycznej analizy literatury i regulacji rachunkowości oraz wykorzystując opisowe statystyki, przeanalizowano dane pochodzące ze sprawozdań finansowych podmiotów niefinansowych notowanych na GPW w Warszawie oraz informacje zawarte w ich KRS.

\section{Kapital podstawowy - znaczenie i pojęcie}

Kapitał podstawowy nie jest jednoznacznie zdefiniowany w regulacjach rachunkowości. W literaturze przedmiotu [np. Gmytrasiewicz i in. 2000, s. 389; Cebrowska 2009, s. 59; Hońko 2015 s. 165; Pfaff 2011, s. 452] kapitał ten jest zazwyczaj zrównany z kapitałem zakładowym określonym w Kodeksie spółek handlowych w odniesieniu do spółek kapitałowych. W tym ujęciu reprezentuje on wartość nominalną wyemitowanych akcji/udziałów.

Należy jednak podkreślić, że z perspektywy ustawy o rachunkowości „kapitał podstawowy" w pewnych okolicznościach oraz dla niektórych typów podmiotów jest pojęciem szerszym. Przykładowo, w przypadku jednostek postawionych w stan likwidacji lub upadłości kapitał (odpowiednio fundusz) podstawowy obejmuje wszystkie składniki kapitału (funduszu) własnego po pomniejszeniu o udziały/akcje własne oraz ewentualne należne wkłady na poczet kapitału w spółce akcyjnej, jeżeli nie wezwano zainteresowanych do ich wniesienia [Ustawa z 29 września 1994, art. 36 ust. 3].

$\mathrm{W}$ polskich regulacjach $\mathrm{w}$ odniesieniu do kapitału podstawowego inne zapisy pojawiają się dla jednostek mikro, będących jednostkami nieprowadzącymi działalności gospodarczej, jak m.in. związki zawodowe, organizacje pracodawców, izby gospodarcze, organizacje samorządu zawodowego. Dla tych podmiotów kapitał podstawowy może obejmować również ustaloną w rachunku zysków i strat dodatnią różnicę między przychodami a kosztami po zatwierdzeniu rocznego sprawozdania finansowego. 
Można wyróżnić kilka cech charakterystycznych kapitału podstawowego, które w niektórych przypadkach można rozszerzyć o inne pozycje kapitału własnego. Są to: - bezterminowość (kapitał podstawowy pozostaje w dyspozycji jednostki bez ograniczeń czasowych lub na cały okres trwania jednostki, jeśli okres ten jest z góry oznaczony). Nieokreślony czas finansowania (bezterminowość) można wskazać jako ogólną cechę kapitału własnego [zob. np. Kiziukiewicz 2007, s. 47; Hońko 2015, s. 165; Buczkowska 2009, s. 282; Błażyńska 2015, s. 351; Gabrusewicz 2014, s. 133; Krzywda 2006], jednak w kontekście kapitału podstawowego nabiera ona szczególnego znaczenia w związku z procedurami dotyczącymi pomniejszania tego kapitału przewidzianymi w Kodeksie spółek handlowych. Inne elementy kapitału własnego (zwłaszcza powstałe z zysku) mogą podlegać dystrybucji na rzecz właścicieli;

- sposób powstania, czyli wniesienie przez właścicieli [zob. np. Brzezin 2006, s. 151-152; Gos 2012, s. 19; Messner, Pfaff 2016, s. 31; Samelak 2006, s. 71; Walińska 2009, s. 86];

- abstrakcyjność ${ }^{3}$;

- prawa podmiotowe do środków gospodarczych [Skrzywan 1973, s. 41];

- funkcja gwarancyjna wobec wierzycieli';

- zapewnienie możliwości kontynuacji działania, czyli źródło finansowania, które uniezależnia od wierzycieli [np. Krzywda 2006, s. 90].

Cechy te wskazują, że informacje na temat wysokości kapitału podstawowego mogą mieć znaczenie dla inwestorów oraz wierzycieli, którzy rozważają swoje zaangażowanie w dany podmiot. $Z$ tego względu informacje na temat kapitału podstawowego wymagane są przez regulacje rachunkowości (m.in. ustawę o rachunkowości). Kwestie prezentacji kapitału podstawowego w sprawozdaniu z sytuacji finansowej (bilansie) regulowane są przez MSR 1 „Prezentacja sprawozdań finansowy” [MSSF 2016]. Standard ten wymaga, aby w bilansie ujawnić wyemitowany kapitał podstawowy oraz kapitały rezerwowe przynależne udziałowcom jednostki dominującej [MSSF 2016, MSR 1, par. 54]. Wyodrębnienie poszczególnych kapitałów własnych uzależnione jest od ich istotności - przygotowując sprawozdanie finansowe, jednostka może dokonać wyodrębnienia znaczących pozycji i dokonać agregacji pozycji nieistotnych. Co charakterystyczne, wskazany wymóg prezentacji kapitału podstawowego dotyczy jedynie pozycji istotnych. Oznacza to, że w przypadku uznania kapitału podstawowego za pozycję nieistotną jednostka może włączyć ją do innej grupy kapitałów własnych.

MSR 1 nie narzuca konkretnych nazw dotyczących pozycji wykazywanych w sprawozdaniu z sytuacji finansowej (bilansie). W związku z tym ,nazwy i kolejność pozycji lub grupy podobnych pozycji można zmieniać stosownie do charakteru

\footnotetext{
${ }^{3}$ Do abstrakcyjności nawiązują m.in. [Gmytrasiewicz i in.2000, s. 390; Walińska 2009, s. 86].

${ }^{4}$ Funkcja gwarancyjna wobec wierzycieli jest wskazana m.in. w opracowaniach Pfaff [2011, s. 452; Krzywda 2011, s. 10].
} 
jednostki i jej transakcji, aby zapewnić informacje, które są potrzebne dla zrozumienia sytuacji finansowej jednostki” [MSSF 2016, MSR 1, par. 57].

\section{Prezentacja kapitału podstawowego zgodnie z MSSF przez spółki notowane na GPW w Warszawie - wyniki badań}

Dla potrzeb niniejszego artykułu przeanalizowano 137 sprawozdania finansowe przygotowane na koniec 2016 r., prezentowane przez spółki niefinansowe notowane na GPW w Warszawie. Spółki do badania wybrano w sposób losowy. Przedmiotem analizy były skonsolidowane sprawozdania finansowe przygotowane na podstawie Międzynarodowych Standardów Sprawozdawczości Finansowej (MSSF), a w przypadku gdy wylosowana jednostka (stosująca MSSF) nie prezentowała sprawozdania skonsolidowanego, sprawozdanie finansowe statutowe. Dodatkowo dla tych podmiotów przeanalizowano dane zawarte w wyciągach z Krajowego Rejestru Sądowego (wyciągi i zawarte w nich informacje pozyskano dla każdej wylosowanej spółki).

Generalnie znacząca większość spośród 137 badanych podmiotów podała w bilansie kapitał podstawowy lub równoznaczny z nim (np. kapitał zakładowy). W badanej grupie jedynie jeden podmiot nie podał bezpośrednio w bilansie kapitału podstawowego (ani tożsamej pozycji). Z kolei inny podmiot dokonał scalenia kapitału podstawowego $\mathrm{z}$ zapasowym, pochodzącym $\mathrm{z}$ agio emisyjnego, i zaprezentował „Kapitał akcyjny i zapasowy ze sprzedaży akcji powyżej ich wartości nominalnej". Przeprowadzona analiza sprawozdań finansowych wskazuje, że niefinansowe podmioty notowane na GPW w Warszawie wykorzystują przedstawione powyżej możliwości swobodnego nazewnictwa kapitału własnego, przy czym określenia te obracają się w grupie „Kapitał podstawowy” (68 podmiotów), „Kapitał zakładowy” (44 podmioty), „Kapitał akcyjny” (14 podmiotów) oraz „Wyemitowany kapitał akcyjny" (5 podmiotów). Jedynie pojedyncze podmioty wprowadzają nieco zmodyfikowane określenia (np. „Kapitał podstawowy (zakładowy)”), które jednak nie powinny mieć istotnego znaczenia dla zrozumienia zaprezentowanych pozycji.

Udział kapitału podstawowego w aktywach i innych kapitałach własnych w badanej grupie jest bardzo zróżnicowany. U 73 podmiotów stanowi mniej niż 5\% aktywów prezentowanych na koniec okresu sprawozdawczego, a u 5 kapitał podstawowy - ponad 95\% (!) aktywów wykazywanych w sprawozdaniu z sytuacji finansowej. Wysoki rozrzut wyraźny jest również w przypadku porównania kapitału podstawowego z sumą kapitałów własnych (z udziałami niekontrolującymi) ${ }^{5} .49$ podmiotów ze 137 badanych (ok. 36\%) wykazywało kapitał podstawowy mniejszy niż 5\% całkowitej wartości kapitału własnego. Z kolei można wskazać 9 podmiotów, u których udział ten był większy niż 95\%. W odniesieniu do zobowiązań rozrzut utrzymywał się na zbliżonym poziomie - 39 spółek z badanych (ok. 28\%) to jednostki, w któ-

\footnotetext{
${ }^{5}$ Średni poziom kapitałów przypisanych do udziałowców niekontrolujących w kapitale własnym podmiotów z badanej grupy wynosi ok. $4 \%$.
} 
rych kapitał stanowił mniej niż 95\% zobowiązań, 13 spółek wykazywało kapitał podstawowy na poziomie wyższym niż 95\% wartości zobowiązań. Relację kapitału podstawowego do zobowiązań w podziale na poszczególne przedziały prezentuje poniższa tabela.

Tabela 1. Relacja kapitału podstawowego do zobowiązań wykazywanych przez niefinansowe podmioty w badanej próbie

\begin{tabular}{|l|c|r|r|r|c|}
\hline & \multicolumn{5}{|c|}{ Kapitał podstawowy do zobowiązań ogółem } \\
\hline Relacja & $<5 \%$ & $\begin{array}{r}5 \%< \\
<30 \%\end{array}$ & $\begin{array}{r}30 \%< \\
<60 \%\end{array}$ & $\begin{array}{r}60 \%< \\
<95 \%\end{array}$ & $>95 \%$ \\
\hline Liczba podmiotów & 39 & 64 & 15 & 6 & 13 \\
\hline $\begin{array}{l}\text { Udział podmiotów } \\
\text { w próbie }\end{array}$ & $28,5 \%$ & $46,7 \%$ & $10,9 \%$ & $4,3 \%$ & $9,6 \%$ \\
\hline
\end{tabular}

Źródło: opracowanie własne na podstawie badania.

Wskazane dane obrazują, że u ponad 75\% podmiotów w badanej próbie kapitał podstawowy utrzymywał się na poziomie niższym niż 30\% zobowiązań. W tym kontekście można stwierdzić, że funkcja gwarancyjna kapitału podstawowego wobec wierzycieli jest bardzo ograniczona. Wydaje się, że lepszym rozwiązaniem (z perspektywy wierzycieli) byłaby prezentacja w kapitałach własnych tych pozycji kapitałów, które nie mogą podlegać dystrybucji na rzecz właścicieli w określonym czasie lub bezterminowo.

W drugiej części badania dokonano porównania kapitału podawanego przez spółki giełdowe w sprawozdaniach finansowych jako kapitału podstawowego z kwotami kapitału zakładowego zarejestrowanego w Krajowym Rejestrze Sądowym. Porównania dokonano na podstawie odpisów (wyciągów) uzyskanych dla każdej z badanych spółek oddzielnie z Centralnej Informacji Krajowego Rejestru Sądowego. Za podstawę analiz przyjęto wysokość kapitału zakładowego podawaną w Dziale 1 Rubryka 8 - Kapitał spółki.

W wyniku porównania ustalono, że $15 \mathrm{z}$ badanych podmiotów (ok. 11\%) wykazuje kapitał podstawowy (odpowiednio zakładowy lub akcyjny) na poziomie innym niż kapitał zarejestrowany w KRS. We wszystkich tych przypadkach kapitał podstawowy prezentowany w sprawozdaniu z sytuacji finansowej był wyższy od kapitału oficjalnie zarejestrowanego w KRS - średnio o 109\%. W pojedynczych przypadkach kapitał podawany jako podstawowy był ponad 6-krotnie wyższy niż zarejestrowany we wspomnianym rejestrze (wyższy o 527\%!). Należy wskazać, że 4 ze wskazanych podmiotów określiły w swoich bilansach omawiany kapitał jako „Kapitał podstawowy”, 7 jako „Kapitał zakładowy”, 2 jako „Kapitał akcyjny”, a 2 inne użyły określeń odpowiednio „Kapitał podstawowy (akcyjny)” i „Kapitał zakładowy (akcyjny)”. Szczególne wątpliwości budzi wykorzystanie w sprawozdaniu finansowym określenia „Kapitał zakładowy” (jak również „Kapitał akcyjny”), z którym Kodeks spółek 
handlowych wiąże wartość nominalną wyemitowanych akcji, podlegającą rejestracji i ujawnieniu w Krajowym Rejestrze Sądowym [Ustawa z 15 września 2000].

Pobieżny przegląd sprawozdań finansowych wskazanych podmiotów dowodzi, że różnice między prezentowanym w sprawozdaniu finansowym kapitałem podstawowym i kapitałem zakładowym ujętym w KRS wynikają z uwzględnienia w nim przeszacowań hiperinflacyjnych (zastosowanie MSR 29 „Sprawozdawczość finansowa w warunkach hiperinflacji”). Należy jednak podkreślić, że wskazane kwoty nie podlegają rygorom kodeksowym (KSH) w zakresie ich zmniejszania, w związku z czym właściciele (walne zgromadzenie akcjonariuszy) mają możliwość ich dystrybucji.

\section{Zakończenie}

Informacje o wysokości kapitału podstawowego mogą mieć istotne znaczenie dla oceny sytuacji finansowej danego podmiotu, zwłaszcza gdy jego udział w finansowaniu aktywów jednostki gospodarczej lub/i zabezpieczeniu wierzycieli jest znaczący. W sytuacji gdy jego wysokość jest niewielka w relacji do aktywów, innych pozycji kapitałów i zobowiązań, wyodrębnianie kapitału podstawowego wydaje się rozwiązaniem, które nie wnosi znaczącego wkładu informacyjnego do oceny sytuacji finansowej danego podmiotu.

Międzynarodowe Standardy Sprawozdawczości Finansowej dają jednostkom gospodarczym podlegającym tym regulacjom znaczną swobodę $\mathrm{w}$ zakresie nazewnictwa pozycji wykazywanych w kapitale własnym. Powoduje to, że jednostki gospodarcze ze zbliżonych sektorów mogą prezentować w kapitale różne pozycje, obejmujące różne elementy. Problem ten dotyka również kapitału podstawowego, który może być prezentowany pod różnymi nazwami. Badania potwierdzają, że niefinansowe spółki giełdowe notowane na GPW w Warszawie wykorzystują różne pojęcia dla takiej pozycji. Odrębna prezentacja kapitału podstawowego, zastosowana przez większość podmiotów w badanej próbie (98\%), daje punkt odniesienia inwestorom i wierzycielom co do stabilności tego źródła finansowania, jednak wykorzystanie różnych określeń wydaje się elementem zmniejszającym porównywalność sprawozdań finansowych, nawet jeśli używane określenia są pojęciowo tożsame.

Badanie wskazuje dodatkowo, że niektóre podmioty prezentują w bilansie (sprawozdaniu z sytuacji finansowej) pod pojęciem „kapitał podstawowy” (lub odpowiednio „kapitał zakładowy” czy „kapitał akcyjny”) kwoty różniące się od kapitału zakładowego zarejestrowanego w Krajowym Rejestrze Sądowym. We wszystkich zidentyfikowanych tego typu przypadkach były to kwoty wyższe (a czasem znacząco wyższe) niż zarejestrowane w KRS. Sytuacja taka może powodować wprowadzenie w błąd inwestorów i wierzycieli, którzy będą bazować jedynie na bilansie jako podstawowym źródle informacji o danym podmiocie i jego kapitale podstawowym. W tym kontekście za szczególnie mylące można uznać wykorzystanie przez niektóre podmioty określenia „,kapitał zakładowy”, którym posługuje się Kodeks spółek han- 
dlowych. Ocena stopnia tego zniekształcenia, jak również wykorzystania informacji o kapitale podstawowym przez dostawców kapitałów wymagałaby jednak:

- analizy ujawnień dotyczących kapitału podstawowego zawartych w informacji dodatkowej. Podmioty wykazujące w sprawozdaniu z sytuacji finansowej kapitał podstawowy w innej kwocie niż kapitał zakładowy zarejestrowany w KRS mogą prezentować w notach uzgodnienia między tymi wielkościami. Nie zmienia to jednak faktu, że bilans sam w sobie (bez dodatkowej analizy informacji dodatkowej) poprzez wykorzystane w nim przyjętego przez spółkę nazewnictwa może wprowadzić w błąd, zwłaszcza gdy inwestorzy porównywaliby podmioty, opierając się na danych pochodzących ze sprawozdania z sytuacji finansowej;

- szerszych badań użytkowników sprawozdań finansowych (oceny, czy biorą oni pod uwagę kapitał podstawowy w swoich analizach dotyczących sytuacji finansowej przedsiębiorstw).

\section{Literatura}

Błażyńska J., 2015, Kapitat (fundusz) własny, [w:] Kamela-Sowińska A., Podstawy rachunkowości w teorii i praktyce, Wydawnictwo Uniwersytetu Ekonomicznego w Poznaniu, Poznań.

Brzezin W., 2006, Ogólna teoria wspótczesnej rachunkowości, Częstochowskie Wydawnictwo Naukowe przy Wyższej Szkole Zarządzania, Częstochowa.

Buczkowska A., 2009, Kapitały, fundusze, rezerwy $i$ wyniki finansowe, [w:] Sawicki K. (red.), Podstawy rachunkowości, PWE, Warszawa.

Cebrowska T., 2009, Problemy ustalania wartości kapitalu własnego, [w:] Buk H., Kostur A. (red.), Zintegrowany system pomiarów dokonań w rachunkowości, Wydawnictwo Akademii Ekonomicznej, Katowice.

Gabrusewicz W., 2014, Analiza finansowa przedsiębiorstwa. Teoria i zastosowanie, PWE, Warszawa. Gmytrasiewicz M., Karmańska A., Olchowicz I., 2000, Rachunkowość finansowa, cz. 1: Wykład, Difin. Gos W., 2012, Bilans. Znaczenie, koncepcje sporzadzania, formy prezentacji, PWE, Warszawa.

Hońko S., 2015, Kapitaty (fundusze) własne, [w:] B. Gierba, W. Gos, S. Hońko, B. Jakubiak, I. Kowalczyk, A. Szczęsna, Rachunkowość finansowa, SKwP, Warszawa.

MSSF 2016, Międzynarodowe Standardy Sprawozdawczości Finansowej, International Financial Reporting Standards, International Accounting Standards Board, London.

Kawa M., 2002, Ewolucja pojęcia majątku jednostki gospodarczej, Zeszyty Teoretyczne Rachunkowości, t. 11 (67).

Kiziukiewicz T., 2007, Rachunkowość nie tylko dla księgowych, PWE, Warszawa.

Krzywda D., 2006, Istota i klasyfikacja kapitalu własnego oraz podstawy prawne jego kreowania w spótkach handlowych, Wyższa Szkoła Ekonomiczna w Bochni, Zeszyty Naukowe 2006, nr 4.

Krzywda D., 2011, Wkłady niepieniężne w ujęciu bilansowym i podatkowym, SKwP, Warszawa.

Messner Z., Pfaff J., 2016, Teoria i zasady rachunkowości, SKwP, Warszawa.

Nowak E., 2011, Rachunkowość. Kurs podstawowy, PWE, Warszawa.

Pfaff J., 2011, Rachunkowość finansowa z uwzględnieniem MSSF, [w:] Messner Z., Pfaff J. (red.), Rachunkowość finansowa, WN PWN, Warszawa.

Samelak J. (red.), 2006, Rachunkowość finansowa. Teoretyczne podstawy, Wydawnictwo Akademii Ekonomicznej w Poznaniu, Poznań.

Skrzywan S., 1973, Teoretyczne podstawy rachunkowości, PWN, Warszawa. 
Ustawa z 15 września 2000 r. Kodeks spółek handlowych, Dz.U. 2016, poz. 1578 ze zm.

Ustawa z 29 września 1994 r. o rachunkowości, Dz.U. 2016, poz. 1047 ze zm.

Walińska E., 2014, Rachunkowość finansowa. Ujęcie sprawozdawcze i ewidencyjne, Wolters Kluwer SA, Warszawa, s. 346.

Walińska E., 2009, Bilans jako fundament sprawozdawczości finansowej w kontekście zmian wspótczesnej rachunkowości, Oficyna Wolters Kluwer business, Warszawa. 